\title{
A Kiss Lajos-díj 2018. évi nyertese: dr. Győrffy Erzsébet
}

A Kiss Lajos-díj alapító okirata szerint a díj odaítélésére 2 vagy 3 évenként kerülhet sor. A díjat a kuratórium első ízben 2006-ban osztotta ki, s ezt követően kétévenként ítélte oda. Az eddigi díjazottak időrendben az alábbiak voltak: Tóth Valéria, Rácz Anita, Farkas Tamás, N. Fodor János, Slíz Mariann és Póczos Rita; közülük hárman a Debreceni Egyetem, hárman pedig az Eötvös Loránd Tudományegyetem oktatói.

A kuratórium 2018-ban arra az álláspontra jutott, hogy az elmúlt két év során a magyar történeti névkutatás általában is és az egyes kutatói teljesítmények tekintetében is olyan jelentős eredményeket ért el, hogy ez a díj újbóli odaítélését ebben az évben minden tekintetben indokolttá teszi.

A kuratórium egyhangú véleménnyel úgy döntött, hogy a Kiss Lajos-díjat 2018-ban az alábbi indokok alapján dr. Győrffy Erzsébetnek, a Debreceni Egyetem Magyar Nyelvtudományi Tanszéke adjunktusának ítéli oda.

Győrffy Erzsébet 1979-ben született Debrecenben, egyetemi tanulmányait a Debreceni Egyetemen végezte 1998-2003 között, és itt kapott magyar nyelv és irodalom - filozófia szakos tanári oklevelet. Ezt követően a nyelvtudományi doktori program magyar nyelvészeti alprogramjának hallgatója lett. 2007-ben tanársegédi kinevezést kapott az egyetem Magyar Nyelvtudományi Tanszékére. 2009-ben summa cum laude minősítéssel szerzett PhD fokozatot, 2011-ben előléptették adjunktusnak. A különböző egyetemi képzési formákban eddig több mint húsz tantárgyat tanított, köztük onomasztikai témájúakat is. 2013-tól oktatóként és témavezetőként vesz részt a Debreceni Egyetem Nyelvtudományok Doktori Iskolájának munkájában. 2017-ben habilitált a Debreceni Egyetemen.

Győrffy Erzsébet kutatói pályája túlnyomórészt a névkutatás területére esik, publikációi két nagy kérdéskört érintenek. Pályája első időszakában elsősorban a magyar víznevek elemzésével foglalkozott. A víznevek kutatása az onomasztikának régóta müvelt kedves területe, amit elsősorban az magyaráz, hogy a nagy folyók nevei minden más helynévfajtánál régebbi múltra vezethetők vissza. A vizeknek a településrendszer szervezésében kitüntetett szerepük van, s a mellettük élö népek egymásnak adják át a megnevezéseiket. Kiss Lajos ezt úgy fogalmazta meg, hogy a nagyobb vizek megnevezései valósággal nemzetközi tulajdonban vannak. A Kárpát-medence víznevei közül nagy figyelmet kaptak a fentiek miatt az ún. óeurópai eredetü víznevek, de sokat írtak a kutatók a szláv eredetü magyar víznevekröl is. Meglepö módon megvilágítatlanul maradtak azonban a magyar nyelv belső keletkezésü víznevei. Győrffy Erzsébet ezek feldolgozásába fogott bele, tanulmányok egész sorában mutatta be nyelvi jellegzetességeiket. Doktori értekezése, majd ennek könyvvé formált változata, a Korai ómagyar kori folyóvíznevek - amely 2011-ben jelent meg A Magyar Névarchívum Kiadványai címú sorozat 20. köteteként - a témakör első monografikus összefoglalása. Jelentőségét hiánypótló jellege is növeli, valamint az a körülmény, hogy az adott korszak víznévanyagát a teljesség igényével tekintette át. Munkája ennek köszönhetően nemcsak e témakörben, hanem 
a névkutatás szélesebb spektrumát illetően is megkerülhetetlen. Győrffy Erzsébet történeti névtani tevékenységének részeként említendő meg az is, hogy közremüködött a Korai magyar helynévszótár 1 . kötetének összeállításában.

Pályájának második szakaszában Győrffy Erzsébet elsősorban helynév-szociológiai kérdéseket vizsgált. A víznévkutatástól eltérően e témakör újnak számít az onomasztika területén. Főleg empirikus vizsgálatok születtek ezen a téren, Győrffy Erzsébet is jó néhány ilyen indíttatású tanulmányt tett közzé. Törekvései azonban a kezdetektől arra irányultak, hogy e tudományterület alapvetését megteremtse, fogalmi hálóját létrehozza. Vizsgálatának eredményeit habilitációs értekezésben foglalta össze, amelynek könyvvé szerkesztett változata Helynév-szociológia címmel az elmúlt napokban látott napvilágot. E munkát nemzetközi tekintetben is úttörő, alapozó müként üdvözölhetjük.

Győrffy Erzsébet termékeny kutató, a fenti két könyve mellett Svédországban is megjelent egy önálló munkája angol nyelven, amely a svéd és a magyar víznévrendszer összevető jellemzését adja. E munka is utal arra, hogy Győrffy Erzsébet megkülönbözetett figyelemmel követi a világviszonylatban is élen járó svéd névkutatást, köszönhetöen annak is, hogy 2006-ban fél évet töltött kutatói ösztöndíjasként az Uppsalai Egyetemen. Nemzetközi kapcsolatai kiválóak, számos rangos nemzetközi konferencián vett részt előadással, folyamatosan publikál a legjelentősebb nemzetközi onomasztikai folyóiratokban. Nemzetközi kapcsolatait kiválóan kamatoztatta és egyben jelentősen bővítette a 2017-ben Debrecenben megrendezett 26. Nemzetközi Névtani Kongresszus szervező bizottságának titkáraként. E rendezvény sikeréhez áldozatos munkájával ő maga is jelentösen hozzájárult.

Győrffy Erzsébet publikációs jegyzéke 48 bibliográfiai tételt tartalmaz, írásai igen változatos, rangos fórumokon jelennek meg. Hatását mutatja, hogy munkáira több mint 200 hivatkozást ismer.

A fentieket figyelembe véve és mérlegelve a Kiss Lajos-díj kuratóriuma úgy döntött, hogy 2018-ban e tudományos díjat az eddigiekben végzett tudományos munkája elismeréseként dr. Győrffy Erzsébetnek ítéli oda.

Debrecen, 2018. június 2.
Dr. Hoffmann István
Dr. Tóth Valéria
Orosz László
Dr. Solymosi László
a kuratórium elnöke
a kuratórium tagja
a kuratórium tagja
a kuratórium tagja

\section{IstVán Hoffmann, Winner of the 2018 Lajos Kiss Prize: Dr Erzsébet Győrffy}

The Lajos Kiss Prize, awarded every two or three years since 2006, is considered to be a highly prestigious award for young onomasticians. The 2018 winner of the prize is Dr Erzsébet Györffy, senior lecturer at the Department of Hungarian Linguistics of the University of Debrecen. She was given this award for her contribution to Hungarian Historical Onomastics, especially for her research on place names and socio-onomastics. 